\title{
Long-Term Outcome of Endoscopic Sinus Surgery in Patients with Aspirin-Exacerbated Respiratory Disease
}

\author{
Dong Jun Lee, Ki Yong Choi, Min Su Kang, Young-Jun Chung, and Ji-Hun Mo \\ Department of Otorhinolaryngology, Dankook University College of Medicine, Cheonan, Korea
}

아스피린 과민성 만성 비부비동염 환자에서 비내시경수술의 장기 추적 결과

이동준 · 최기용 · 강민수 · 정영준 · 모지훈

단국대학교 의과대학 이비인후-두경부외과학교실

\author{
Received June 18, 2017 \\ Revised August 16, 2017 \\ Accepted September 11, 2017 \\ Address for correspondence \\ Ji-Hun Mo, MD, PhD \\ Department of Otorhinolaryngology, \\ Dankook University \\ College of Medicine, \\ 201 Manghyang-ro, Dongnam-gu, \\ Cheonan 31116, Korea \\ Tel $+82-41-550-3933$ \\ Fax $+82-41-556-1090$ \\ E-mail jihunmo@gmail.com
}

Background and Objectives Patients with aspirin-exacerbated respiratory disease (AERD) tend to have more severe clinical course and also tend to be recalcitrant to conventional medical and surgical treatment. This study aimed to assess the long-term outcome of endoscopic sinus surgery in AERD patients.

Subjects and Method Fifteen patients with AERD $(n=15)$ were identified through a retrospective chart review, and compared with 74 patients of CRSwNP (with asthma $n=23$; without asthma $\mathrm{n}=51$ ) by analyzing preoperative and postoperative symptoms, endoscopic score, LundMackay CT score, number of revision surgery or outpatient procedures, frequency of clinic visits and medications. The CRS control status was evaluated according to the European Position Paper on Rhinosinusitis and Nasal Polyps 2012 criteria and logistic regression analyses were conducted to investigate the determining factors of preoperative and postoperative symptoms. Results The AERD group showed higher disease severity than other groups preoperatively: endoscopic score (CRSwNP s asthma $6.3 \pm 2.6$ vs. CRSwNP c asthma $6.5 \pm 2.3$ vs. AERD $8.8 \pm 1.4, p<0.05)$, CT score $(12.2 \pm 4.9$ vs. $17.0 \pm 4.8$ vs. $18.0 \pm 2.1, p<0.05)$, and overall symptom score ( $30.8 \pm 0.4$ vs. $33.8 \pm 1.5$ vs. $37.9 \pm 0.7, p<0.01)$. The rate of revision surgery and outpatient procedures, postoperative clinic visit and prescription rate were higher in the AERD group $(p<$ 0.05 , respectively). However, postoperative symptom scores and CRS control status were not significantly different among three groups ( $p=0.267$ and $p=0.996$, respectively).

Conclusion Although AERD patients showed higher preoperative endoscopic scores and revision surgery rates, postoperative subjective symptoms were comparable to those of other groups with long-term follow up, suggesting the importance of frequent outpatient care after endoscopic sinus surgery. Korean J Otorhinolaryngol-Head Neck Surg 2018;61(4):193-9

Key Words AERD $\cdot$ Chronic rhinosinusitis · Endoscopic sinus surgery.

\section{서 론}

아스피린 과민성 호흡기 질환(aspirin-exacerbated respiratory disease, AERD)은 non-steroidal anti-inflammatory

This is an Open Access article distributed under the terms of the Creative Commons Attribution Non-Commercial License (http://creativecommons.org/licenses/by-nc/4.0) which permits unrestricted non-commercial use, distribution, and reproduction in any medium, provided the original work is properly cited.
drugs(NSAID)-exacerbated respiratory disease라고 부르 기도 하며, 천식과 비용(polyp), 아스피린(acetylsalicylic acid) 및 비스테로이드성 소염진통제(NSAIDs)에 대한 급성 상-하부 호흡기계의 과민 반응을 의미한다. $\mathrm{AERD}$ 는 일반 적인 내과적 약물 치료에 잘 반응하지 않으며, 부비동 내시경 수술 후에도 재발률이 높은 것으로 알려져 있다. ${ }^{1)} \mathrm{AERD}$ 연 구의 초창기인 1922년에 Widal은 아스피린 및 비스테로이드 
성 소염진통제에 대한 과민성, 비용(polyp), 천식의 삼징후에 대해 처음 기술하였고, 이후 Samter와 Beers ${ }^{2}$ 에 의해 체계적 으로 연구되었다. 통상적으로 Samter 삼징후는 AERD와 같 은 의미로 쓰여지고 있으며, 아스피린 과민성은 $\operatorname{IgE}$ 매개 과민 반응이 아니라 Eicosanoid 합성 장애가 원인으로 알려져 있 다. 결과적으로 류코트리엔이 과다 분비되면서 염증 상태가 되는데, 실제 AERD 환자의 비점막을 조직 검사해 보면 류코 트리엔 수용체가 과발현되어 있는 것을 확인할 수 있다. ${ }^{3}$

$\mathrm{AERD}$ 의 내과적 혹은 외과적 치료 성적은 일반적인 비용 환자군에 비해 좋지 않다고 알려져 있다. 실제로 Amar 등ㄹ 의 보고에 의하면 Samter 삼징후 환자 18명 중 7명(39\%)이 재발로 인해 재수술을 받았고, 국내에서도 16 명의 Samter 삼 징후 환자를 대상으로 한 연구에서 $88 \%$ 의 재발률과 $50 \%$ 의 재수술률을 보고하였다. ${ }^{4)}$ 하지만 높은 재발률에도 불구하고 비내시경수술이 환자의 비증상 및 삶의 질을 호전시킨다고 보고되었다. ${ }^{5,6)}$

$\mathrm{AERD}$ 환자의 희소성으로 인해 국내에서는 $\mathrm{AERD}$ 환자의 비내시경수술 이후 치료 성적에 대한 보고는 2건에 불과하 며, 특히 천식과 아스피린 과민성, 흡연력, 알러지, 성별 등 수 술 전과 후의 환자 증상에 영향을 미칠 수 있는 인자들에 대한 연구는 아직까지 보고된 바 없다. 이에 저자들은 AERD 환자 와 아스피린 과민성 없이 천식을 동반한 비부비동염 환자 그리 고 천식과 아스피린 과민성을 동반하지 않는 비부비동염 환자 를 장기 추적관찰한 후 수술 전후의 증상을 비교함과 동시에 이러한 증상에 영향을 미치는 인자들을 분석하고자 하였다.

\section{대상 및 방법}

\section{대 상}

단국대학교병원 이비인후과에서 2011년 7월부터 2014년 6월
까지 AERD로 비내시경수술을 받은 환자 15명, 아스피린 과 민성 없이 천식을 동반한 비부비동염 환자 23명, 천식과 아스 피린 과민성이 모두 없는 비부비동염 환자 51명을 대상으로 하였다. 89명의 환자들은 모두 비내시경수술 이후 최소 30 개 월 이상의 외래 추적관찰 기간을 가졌으며, 양측 만성 비부비 동염으로 수술받은 환자 중 알레르기 피부반응검사를 통해 알레르기 비염 여부를 확인할 수 있는 환자에 한정하여 연구 대상자를 선별하였다.

$\mathrm{AERD}$ 의 진단은 1) 비내시경검사에서 양측 비용이 존재 하고, 2) 의무기록에 반복적인 아스피린 과민 반응이 기재되 어 있으며, 3) 본원 호흡기내과에서 천식으로 확진받은 환자 에 한정하여 이루어졌다. 이들은 3개월 이상의 국소 스테로이 드 및 경구 항생제, 경구 스테로이드 등의 약물 치료를 받았 으나, 증상 호전을 보이지 않아 비내시경수술을 시행하였다.

\section{수술 전후 평가}

술 전 평가로 비내시경검사, 알레르기 피부반응검사, 컴퓨 터단층촬영을 시행하였고, 환자들이 주로 호소하는 비폐색, 비루, 두통, 안면 압박감 또는 안면통, 후각 장애의 5 개 항목에 대해 각각 0 10점으로 술 전에 설문조사를 시행하였다. 수 술 후 평가에는 술 전 평가 시 사용된 증상 설문과 함께 비내 시경검사가 포함되었고, European Position Paper on Rhinosinusitis and Nasal Polyps(EPOS) 2012 지침에 따른 전화 설 문을 추가적으로 실시하였다. ${ }^{7)}$ EPOS 2012 지침에 따라 비폐 색, 비루 및 후비루, 안면통 및 두통, 후각 소실, 수면 장애, 최근 3개월 이내 전신 스테로이드나 항생제 사용력을 조사한 이후 위 항목에 하나도 해당하지 않거나 일상 생활에 전혀 지 장을 받지 않을 경우를 조절군(controlled group), 위 항목 중 최소 하나 이상에 해당될 경우 부분 조절군(partly controlled group), 3 가지 이상의 항목에 해당될 경우 조절되지 않는 군

Table 1. Assessment of current clinical control of chronic rhinosinusitis by European Position Paper on Rhinosinusitis and Nasal Polyps 2012

\begin{tabular}{|c|c|c|c|}
\hline Characteristic & Controlled (all of the following) & Partly controlled (at least 1) & $\begin{array}{l}\text { Uncontrolled ( } \geq 3 \text { features } \\
\text { of partly controlled) }\end{array}$ \\
\hline Nasal blockage & Not present or not bothersome & $\begin{array}{l}\text { Present on most days of the } \\
\text { week }\end{array}$ & \\
\hline Rhinorrhea/PND & Little and mucous & $\begin{array}{l}\text { Mucopurulent on most days } \\
\text { of the week }\end{array}$ & \\
\hline Facial pain/headache & Not present or not bothersome & Present & \\
\hline Loss of sense of smell & Not present or not bothersome & Present & \\
\hline Sleep disturbance/fatigue & Not/slightly present & Present & \\
\hline Nasal endoscopy & Healthy or almost healthy mucosa & Diseased mucosa & \\
\hline Systemic medication & Not needed & $\begin{array}{l}\text { A course of antibiotics/ } \\
\text { systemic corticosteroids } \\
\text { in the last } 3 \text { months }\end{array}$ & $\begin{array}{l}\text { Long term antibiotics/systemic } \\
\text { corticosteroids in the last } \\
\text { months }\end{array}$ \\
\hline
\end{tabular}

PND: post nasal drip 
(uncontrolled group)으로 구분하였다(Table 1).

수술 전 시행한 컴퓨터단층촬영 소견으로 양측 전두동, 상 악동, 사골동, 접형동, 부비동 개구연합 총 10 개 공간에 혼탁 도 정도에 따라 $0,1,2$ 점으로 점수를 배정하여 Lund-Mackay $\mathrm{CT}$ 점수를 계산하였다. 비내시경 소견은 Lund-Kennedy 내 시경 점수를 이용하여 비분비물, 부종, 가피, 반흔, 비용종에 대해 $0,1,2$ 점으로 점수를 배정하여 합산하였다.

또한 내시경수술 이후 객관적인 효과 평가를 위해 수술 후 환자들의 외래 방문 횟수와 투약 횟수 및 재수술 여부를 분 석하였다. 재수술은 증상 및 폴립의 재발에 따라 내과적 약 물 치료에 실패한 환자에 한하여 실시하였으며, 외래에서 국 소마취하에 간단히 시행한 시술(outpatient procedure) 횟수 도 분석하였다.

\section{통계학적 분석}

통계학적 처리는 SPSS 13.0(SPSS software, SPSS Inc., Chicago, IL, USA)을 이용하였으며, 각 군별 증상 비교를 위 해 일원배치분산분석을, EPOS 2012 지침에 따른 각 군별 증 상 조절 비교는 카이제곱 검정을 이용해 분석하였다. 또한 성 별 및 천식, 흡연력, 알러지 유무, 아스피린 과민성이 수술 전 후 환자의 증상에 미치는 영향을 분석하기 위해 다중회귀분 석을 사용하였으며, $p$ 값이 0.05 미만인 경우를 통계적으로 유의한 차이가 있다고 평가하였다.

\section{결 과}

\section{인구 통계학적 특성 및 술 전 평가}

천식과 아스피린 과민성이 없는 비부비동염 환자들(대조 군, $n=51$ )의 평균 연령은 $41.0 \pm 4.2$ 세로 남자가 34 명, 여자가
17 명이었다. 아스피린 과민성은 없이 천식을 동반한 비부비동 염 환자들(천식군, $\mathrm{n}=23$ )의 평균 연령은 $45.5 \pm 3.9$ 세로 남자

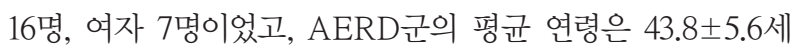
로 남자 9명, 여자 6명이었다.

수술 전 Lund-Mackay 점수는 대조군 $12.2 \pm 4.9$, 천식군 17.0 $\pm 4.8, \mathrm{AERD}$ 군 $18.0 \pm 2.1$ 로 $\mathrm{AERD}$ 군이 다른 두 군보다 유의 하게 높았으며 $(p=0.032)$, 수술 전 Lund-Kennedy 점수도 대

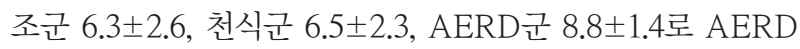
군에서 다른 두 군에 비해 유의하게 높았다 $(p=0.024)$.

알레르기 피부반응검사와 알레르기 비염증상조사를 통한 알레르기 비염 진단결과 알레르기 비염으로 진단된 환자는 대 조군 22명, 천식군 15 명, $\mathrm{AERD}$ 군 7 명이었다. 대조군 22명 중 통년성 알레르기 비염 환자는 10 명, 계절성 알레르기 비염 환자는 12 명이었고, 천식군 15 명 중 통년성 알레르기 비염 환 자는 7명, 계절성 알레르기 비염 환자는 8명이었으며, AERD 군 7명 중 통년성 알레르기 비염 환자는 2 명, 계절성 알레르기 비염 환자는 5 명이었다.

세 군의 평균 추적관찰 기간은 각각 $33.2 \pm 3.1,38.1 \pm 2.9$, $34.2 \pm 2.6$ 개월로 세 군 간의 차이는 없었다 $(p=0.532)$ (Table 2).

\section{수술 전 후 증상 및 만성 부비동염 조절 상태}

수술 전후 비폐색, 비루, 두통, 안면 압박감 또는 안면통, 후 각 장애의 5 가지 항목에 대해 각각 0 10점을 배점으로 모든 항목의 점수를 합산하여 비교한 결과 수술 전 증상 점수는 대조군 $30.8 \pm 0.4$, 천식군 $33.8 \pm 1.5, \mathrm{AERD}$ 군 $37.9 \pm 0.7$ 로 $\mathrm{AERD}$ 군에서 유의하게 높았으며 $(p<0.01)$, 수술 후 증상 점 수는 대조군 $11.0 \pm 0.8$, 천식군 $11.3 \pm 0.6, \mathrm{AERD}$ 군 $11.4 \pm 0.9$ 로 세 군 간 차이는 관찰되지 않았다 $(p=0.267)$ (Fig. 1).

EPOS 2012 지침에 따라 평가한 결과 조절되지 않는 환자

Table 2. Demographic data and preoperative assessment

\begin{tabular}{|c|c|c|c|c|}
\hline & CRSwNP s asthma $(n=51)$ & CRSwNP c asthma $(n=23)$ & $\operatorname{AERD}(n=15)$ & $p$ value \\
\hline Mean age & $41.0 \pm 4.2$ & $45.5 \pm 3.9$ & $43.8 \pm 5.6$ & 0.342 \\
\hline Male (\%) & $34(66.7)$ & $16(69.5)$ & $9(60.0)$ & \\
\hline Female (\%) & 17(33.3) & $7(30.5)$ & $6(40.0)$ & \\
\hline Lund-Mackay score & $12.2 \pm 4.9$ & $17.0 \pm 4.8$ & $18.0 \pm 2.1$ & 0.032 \\
\hline Lund-Kennedy score & $6.3 \pm 2.6$ & $6.5 \pm 2.3$ & $8.8 \pm 1.4$ & 0.024 \\
\hline AR & & & & - \\
\hline AR & 22 & 15 & 7 & \\
\hline Non AR & 29 & 8 & 8 & \\
\hline Total lg E (IU/mL) & & & & - \\
\hline$A R$ & $319.2 \pm 36.9$ & $294.6 \pm 42.3$ & $948.2 \pm 121.9$ & \\
\hline Non AR & $178.6 \pm 93.2$ & $192.3 \pm 51.2$ & $649.3 \pm 42.9$ & \\
\hline Mean follow up period (month) & $33.2 \pm 3.1$ & $38.1 \pm 2.9$ & $34.2 \pm 2.6$ & 0.532 \\
\hline
\end{tabular}

Values are presented as number or mean \pm standard deviation. CRSWNP: chronic rhinosinusitis with nasal polyps, AERD: aspirin-exacerbated respiratory disease, AR: allergic rhinitis 
비율은 대조군 $27.4 \%$, 천식군 $22.6 \%, \mathrm{AERD}$ 군 $25.4 \%$ 였으며, 부분 조절된 환자의 비율은 $51.1,58.9,54.1 \%$ 였고, 조절이 잘 된 환자의 비율은 각각 $21.5,18.5,20.5 \%$ 로 세 군 간 차이는 없었다 $(p=0.996)$ (Fig. 2).

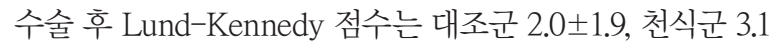

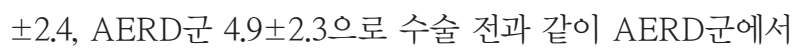
통계적으로 유의하게 높은 점수를 보였다(Fig. 3).

\section{술 후 추적 관찰 양상 비교}

수술 후 외래 추적 관찰 횟수는 대조군 $7.0 \pm 3.8$, 천식군 8.8 $\pm 5.3, \mathrm{AERD}$ 군 $16.1 \pm 11.9$ 로 다른 두 군에 비해 $\mathrm{AERD}$ 군 에서 유의하게 많은 방문 횟수를 보였고 $(p<0.01)$ (Fig. 4). 추

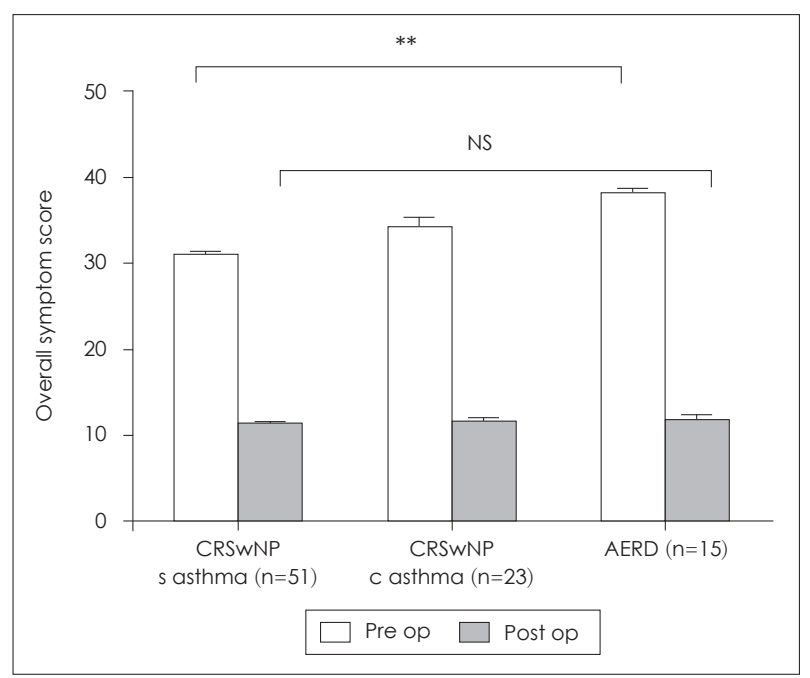

Fig. 1. Overall symptom score before and after surgery. AERD group had significantly higher pre-op symptom score, however, there was no statistically significant difference in postoperative symptom score among the three groups. ${ }^{*} p<0.05$, ${ }^{* *} p<0.01$. CRSwNP: chronic rhinosinusitis with nasal polyps, AERD: aspirin-exacerbated respiratory disease, NS: non-significant, op: operative.

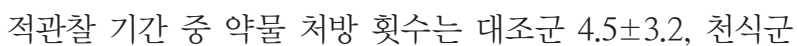
$5.9 \pm 4.0, \mathrm{AERD}$ 군 $10.7 \pm 7.8$ 로 $\mathrm{AERD}$ 군에서 유의하게 높은 투약 빈도를 보였다 $(p<0.01)$ (Fig. 4).

수술 후 추적관찰 기간 중 재수술을 시행하거나 외래 시술 을 시행한 경우를 분석한 결과에서는 재수술을 시행한 경우가 각 군별로 $1.9,0.0,13.3 \%$ 였고, 외래 시술을 시행한 경우는 $5.9,26.0,33.3 \%$ 였다. 모든 경우를 합산했을 때 각 군별로 $7.8,26.0,46.6 \%$ 로 $\mathrm{AERD}$ 군에서 술 후 재수술과 외래 시술 의 비율이 유의하게 높았다 $(p<0.05)$ (Table 3).

\section{수술 전 후 증상에 대한 다인자 분석}

수술 전 증상(preoperative overall symptom)에 영향을 미 치는 인자에 대한 다중회귀분석 결과 성별 및 천식, 흡연력,

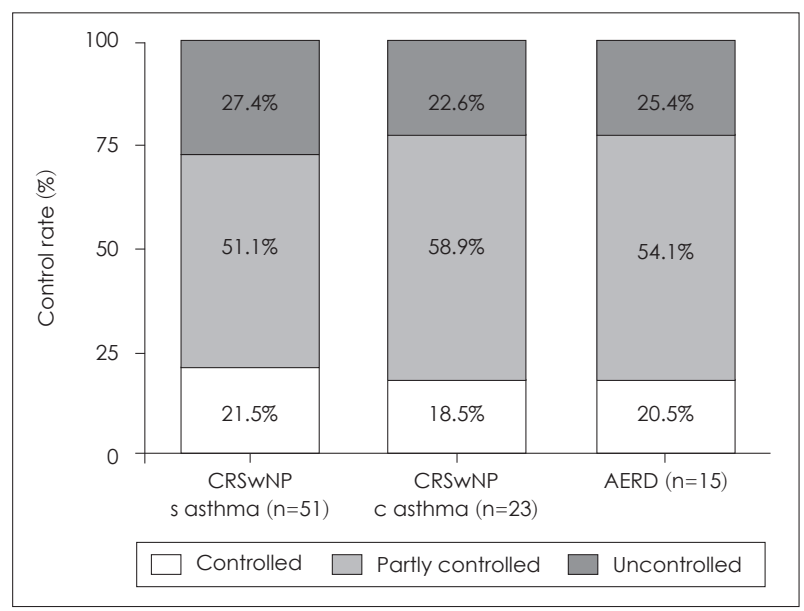

Fig. 2. Assessment of current clinical control status. When comparing the control status according to European Position Paper on Rhinosinusitis and Nasal Polyps 2012 criteria, there was no statistically significant difference among the three groups. CRSwNP: chronic rhinosinusitis with nasal polyps, AERD: aspirinexacerbated respiratory disease.
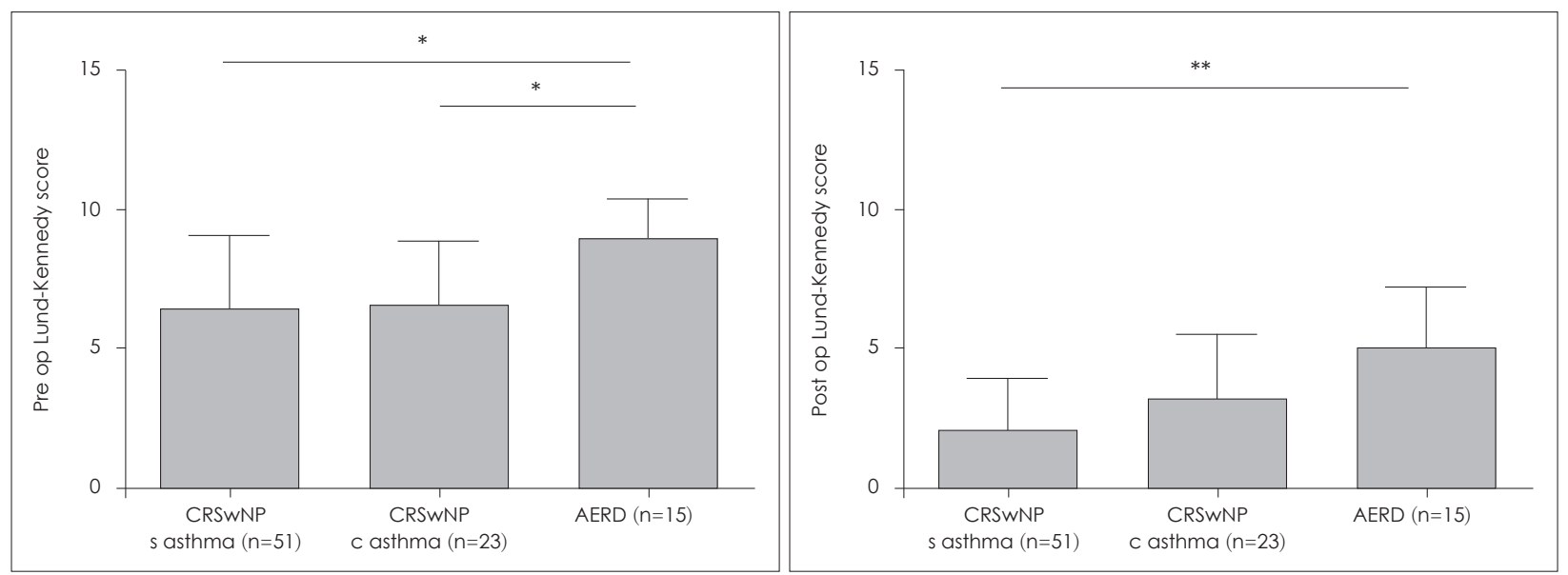

Fig. 3. Preoperative and postoperative Lund-Kennedy score. AERD group showed higher pre and postoperative Lund-Kennedy score than other groups. ${ }^{*} p<0.05$, ${ }^{* *} p<0.01$. CRSwNP: chronic rhinosinusitis with nasal polyps, AERD: aspirin-exacerbated respiratory disease. 
알러지 유무, 아스피린 과민성 모두 수술 전 증상과 연관성을 가지지 않았으며 $(p>0.05)$, 수술 후 증상(postoperative overall symptom)은 여러 인자 중 성별과 연관성을 가지고 있었 으며, 남자보다 여자에서 불량한 예후를 보였다 $(p<0.001)$ (Table 4).

\section{고 찰}

천식, 아스피린 과민성, 비용을 동반한 비부비동염의 삼징
후를 특징으로 하는 $\mathrm{AERD}$ 는 전체 천식 환자 중 약 $7 \%$ 를 차 지하며, 여성에서 유병률이 높다고 알려져 있다.8) 비루, 비폐색 으로 시작되는 임상 증상은 20 30대에 처음 시작되며 이후 재발성 부비동염, 천식과 아스피린 과민성 순으로 발병한다. 천식과 부비동염은 같은 호흡기도의 염증 반응으로 두 질환 이 흔히 동반되는 특성 때문에 두 질환의 연관성에 대한 보고 들이 많으나," AERD 환자의 비내시경수술 이후 예후에 대한 보고는 드물다.

통상적으로 $\mathrm{AERD}$ 는 약물 치료에 잘 반응하지 않으며, 일

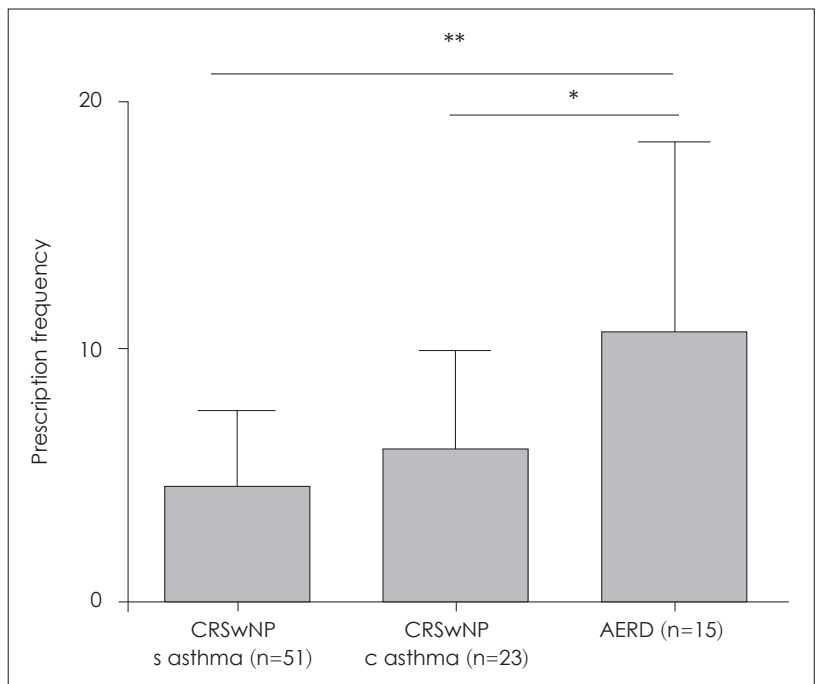

Fig. 4. Postoperative clinic visits and prescription frequency. AERD group visited clinic more frequently and showed higher prescription frequency than other groups. ${ }^{*} p<0.05,{ }^{* *} p<0.01$. CRSwNP: chronic rhinosinusitis with nasal polyps, AERD: aspirin-exacerbated respiratory disease.

Table 3. The number of revision surgery and outpatient procedure

\begin{tabular}{lccc}
\hline \multicolumn{1}{c}{ No. } & CRS w NP s asthma $(\mathrm{n}=51)$ & CRS w NP c asthma $(\mathrm{n}=23)$ & AERD $(\mathrm{n}=15)$ \\
\hline Revision surgery $(\%)$ & $1(1.9)$ & $0(0.0)$ & $2(13.3)$ \\
Outpatient procedure $(\%)$ & $3(5.9)$ & $6(26.0)$ & $5(33.3)$ \\
\hline Total $(\%)$ & $4(7.8)$ & $6(26.0)$ & $7(46.6)$ \\
\hline
\end{tabular}

No.: number, CRSWNP: chronic rhinosinusitis with nasal polyps, AERD: aspirin-exacerbated respiratory disease

Table 4. Multiple regression analysis of determining factors of preoperative and postoperative symptoms

\begin{tabular}{|c|c|c|c|c|}
\hline Variable & $\beta$ & SE & $95 \% \mathrm{Cl}$ & $p$ value \\
\hline \multicolumn{5}{|l|}{ Preoperative symptoms } \\
\hline Sex & -0.186 & 0.773 & $(-1.888-1.517)$ & 0.815 \\
\hline Asthma & -1.500 & 1.392 & $(-3.532-2.412)$ & 0.301 \\
\hline Smoking & 1.679 & 1.075 & $(-0.687-4.045)$ & 0.147 \\
\hline Allergy & -0.179 & 1.075 & $(-2.545-2.187)$ & 0.871 \\
\hline Aspirin intolerance & -1.500 & 1.392 & $(-3.532-2.412)$ & 0.301 \\
\hline \multicolumn{5}{|l|}{ Postoperative symptoms } \\
\hline Sex & 3.400 & 0.571 & $(2.144-4.656)$ & $<0.001$ \\
\hline Asthma & 2.214 & 2.077 & $(0.126-5.714)$ & 0.306 \\
\hline Smoking & 1.500 & 0.793 & $(-0.246-3.246)$ & 0.085 \\
\hline Allergy & 0.500 & 0.793 & $(-1.246-2.246)$ & 0.541 \\
\hline Aspirin intolerance & 2.214 & 2.077 & $(0.126-5.714)$ & 0.306 \\
\hline
\end{tabular}

SE: standard error, $\mathrm{Cl}$ : confidence interval 
반적인 비부비동염 환자에 비해 증상 및 비용의 재발로 인한 재 수술의 비율이 높은 것으로 알려져 있다. Kim과 Kountakis ${ }^{10)}$ 는 비내시경수술 이후 $\mathrm{AERD}$ 군의 재수술률이 대조군에 비 해 10 배 높다고 보고하였으며, 수술 6 개월 이후 비폐색, 안면 통, 후비루, 후각 장애, 비용의 재발이 대조군보다 유의하게 높다고 하였다. McFadden 등 ${ }^{11)}$ 은 비내시경수술 이후 80명의 $\mathrm{AERD}$ 환자들을 대상으로 한 장기 추적 연구에서 $\mathrm{AERD}$ 환자의 재수술률과 안구 합병증의 빈도가 높다고 하였다.

하지만 재수술 비율이 높음에도 불구하고 수술 이후 AERD 환자들의 비증상과 삶의 질은 일반적인 비부비동염으로 내 시경수술을 받은 환자군과 통계학적 차이가 없다는 연구들 도 보고되고 있다. Schaitkin 등 ${ }^{12)}$ 은 비내시경수술 이후 4년 간 $\mathrm{AERD}$ 환자를 추적관찰한 결과에서 $82 \%$ 가 주관적인 비 증상이 개선됨을 확인하였으며, Amar 등ํㅡㄴ 18 명의 AERD 환자를 대상으로 한 연구에서 후비루와 후각 소실 외 모든 비 증상들이 호전되었다고 보고하였다. 또한 Jang 등 ${ }^{13)}$ 은 32명 의 AERD 환자들을 3년 이상 장기 추적관찰하여 대조군과 비교한 연구에서 Sino-Nasal Outcome Test(SNOT)-20 점수 가 차이가 없었다고 보고하였다. 본 연구에서 수술 전과 후의 Lund-Kennedy 내시경 점수를 살펴보았을 때 AERD군이 다른 군에 비해 질병 심각도(disease severity)가 높음에도 불 구하고, 수술 후 증상 점수는 다른 군과 차이를 보이지 않았 으며, EPOS 2012 지침에 따른 비부비동염의 조절 상태 비교 에서도 $\mathrm{AERD}$ 군이 천식군 및 대조군과 유의한 차이를 보이 지 않았다. 이는 AERD 환자들이 비내시경수술 이후 외래에 서 시술을 받는 비율과 투약 횟수가 다른 군보다 높다는 사 실에 비추어 보았을 때, $\mathrm{AERD}$ 환자들의 전반적인 증상이나 만성 비부비동염 조절에, 빈번한 외래 방문을 통한 환자 관 리가 중요한 역할을 한다는 것을 유추할 수 있다.

$\operatorname{Kim}$ 등 $^{4}$ 은 AERD 환자들의 내시경수술 이후 비폐색과 후 비루의 호전이 각각 $88,73 \%$ 로 높았고 객관적 재발 소견과 주관적 증상의 불일치 원인으로 적은 비용이 자라 주관적인 증상을 나타내기까지 수년이 걸린다고 분석하였는데, 본 연 구에서 장기간 $\mathrm{AERD}$ 환자를 추적관찰한 결과 이미 비용이 자라기 전에 외래에서 약물 및 시술을 통해 환자의 증상 재발 을 예방하는 것이 환자의 주관적 증상 개선에 어느 정도 역할 을 하고 있는 것으로 보인다. 또한 이러한 결과는 AERD가 일 회성 수술이나 약물 치료로 해결되지 않고 장기적인 관리가 필 요함을 의미한다.

실제로 $\mathrm{AERD}$ 의 치료는 다각적인 접근법이 필요하다. 본 연구에서는 환자들이 내시경수술 이후 아스피린 탈감작을 시행하지 않았으나, Cho 등 ${ }^{14)}$ 은 21 명의 AERD 환자들을 비 내시경수술 후 4주 뒤부터 아스피린 탈감작을 시행하여 30
개월의 추적관찰 기간 동안 재수술을 받은 환자가 없었음을 보고해 술 후 아스피린 탈감작의 유용함을 주장하였고, MacMain과 Kountakis ${ }^{15)}$ 도 내시경수술 이후 AERD군을 대조군과 비교한 연구에서 2년 뒤 삶의 질 지표인 SNOT-20 에는 차이가 없었으며, 아스피린 탈감작이 재수술률을 낮춰 준다고 보고하였다.

AERD 환자의 내시경수술 이후 증상에 영향을 미칠 수 있 는 다인자 분석에서 성별, 천식, 흡연력, 알러지 유무, 아스피 린 과민성 중 성별만이 수술 후 증상과 유의한 연관성을 보 였으며, 여성이 남성보다 예후가 좋지 않음을 확인할 수 있었 다. 이는 여성에서 증상의 시작이 남자보다 빠르고, 질병 진행 이 더욱 심하다고 한 Szczeklik 등 ${ }^{16)}$ 의 연구결과와 일치한다. 또한 Smith 등 ${ }^{17)}$ 은 19 명의 AERD 환자를 대상으로 내시경수 술을 시행한 후 1.4년 뒤의 Rhinosinusitis Disability Index, Chronic Sinusitis Survey를 분석한 결과에서 수술 후 삶의 질이 유의하게 향상되었고, 아스피린 과민성 여부는 결과에 영향을 미치지 않는다고 분석하였는데, 이는 본 연구와도 일 치한다.

이상의 연구결과에서 비내시경수술이 질병 진행을 안정화시 키고, ${ }^{18)}$ 재수술 비율이 높음에도 불구하고 수술 이후 AERD 환자들의 삶의 질이나 비증상이 대조군과 유의한 차이를 보 이지 않는다는 사실은 비내시경수술의 유용성을 보여준다 하겠다.

\section{Acknowledgments}

This research was supported by Basic Science Research Program through the National Research Foundation of Korea (NRF) funded by the Ministry of Education (NRF-2016R1A2B4010407).

\section{REFERENCES}

1) Amar YG, Frenkiel S, Sobol SE. Outcome analysis of endoscopic sinus surgery for chronic sinusitis in patients having Samter's triad. J Otolaryngol 2000;29(1):7-12.

2) Samter M, Beers RF Jr. Concerning the nature of intolerance to aspirin. J Allergy 1967;40(5):281-93.

3) Sousa AR, Parikh A, Scadding G, Corrigan CJ, Lee TH. Leukotrienereceptor expression on nasal mucosal inflammatory cells in aspirinsensitive rhinosinusitis. N Engl J Med 2002;347(19):1493-9.

4) Kim JC, Kim CJ, Kim YJ, Lee BJ, Lee SK. Effect of endoscopic sinus surgery in Samter's triad patients. Korean J Otorhinolaryngol-Head Neck Surg 2003;46(2):126-30.

5) Awad OG, Lee JH, Fasano MB, Graham SM. Sinonasal outcomes after endoscopic sinus surgery in asthmatic patients with nasal polyps: a difference between aspirin-tolerant and aspirin-induced asthma? Laryngoscope 2008;118(7):1282-6.

6) Robinson JL, Griest S, James KE, Smith TL. Impact of aspirin intolerance on outcomes of sinus surgery. Laryngoscope 2007;117 (5):825-30.

7) Fokkens WJ, Lund VJ, Mullol J, Bachert C, Alobid I, Baroody F, et al. EPOS 2012: European position paper on rhinosinusitis and nasal polyps 2012. A summary for otorhinolaryngologists. Rhinology 2012; 50(1):1-12. 
8) Rajan JP, Wineinger NE, Stevenson DD, White AA. Prevalence of aspirin-exacerbated respiratory disease among asthmatic patients: A meta-analysis of the literature. J Allergy Clin Immunol 2015;135 (3):676-81.e1.

9) Dhong HJ, Ha BS, Jung YS, Chung SK, Chang BC. Clinical characteristics of chronic sinusitis with asthma. Korean J Otorhinolaryngol-Head Neck Surg 2000;43(5):514-9.

10) Kim JE, Kountakis SE. The prevalence of Samter's triad in patients undergoing functional endoscopic sinus surgery. Ear Nose Throat J 2007;86(7):396-9.

11) McFadden EA, Woodson BT, Fink JN, Toohill RJ. Surgical treatment of aspirin triad sinusitis. Am J Rhinol 1997;11(4):263-70.

12) Schaitkin B, May M, Shapiro A, Fucci M, Mester SJ. Endoscopic sinus surgery: 4-year follow-up on the first 100 patients. Laryngoscope 1993;103(10):1117-20.

13) Jang DW, Comer BT, Lachanas VA, Kountakis SE. Aspirin sensitivity does not compromise quality-of-life outcomes in patients with
Samter's triad. Laryngoscope 2014;124(1):34-7.

14) Cho KS, Soudry E, Psaltis AJ, Nadeau KC, McGhee SA, Nayak JV, et al. Long-term sinonasal outcomes of aspirin desensitization in aspirin exacerbated respiratory disease. Otolaryngol Head Neck Surg 2014;151(4):575-81.

15) McMains KC, Kountakis SE. Medical and surgical considerations in patients with Samter's triad. Am J Rhinol 2006;20(6):573-6.

16) Szczeklik A, Nizankowska E, Duplaga M. Natural history of aspirininduced asthma. AIANE investigators. European Network on aspirininduced asthma. Eur Respir J 2000;16(3):432-6.

17) Smith TL, Mendolia-Loffredo S, Loehrl TA, Sparapani R, Laud PW, Nattinger AB. Predictive factors and outcomes in endoscopic sinus surgery for chronic rhinosinusitis. Laryngoscope 2005;115(12):2199205.

18) Olivier F, George M, Leuba D, Monnier P, Friedrich JP. Long-term outcomes following functional endoscopic sinus surgery in Samter's triad. J Laryngol Otol 2015;129(6):548-52. 